\title{
Root Length Density in Maize/Cowpea Intercropping under a Basin Tillage System in a Semi-Arid Area of Zimbabwe
}

\author{
E. D. N. Dube' ${ }^{1}$ T. Madanzi ${ }^{1}$, A. Kapenzi ${ }^{2}$, E. Masvaya ${ }^{3}$ \\ ${ }^{1}$ Midlands State University, Agronomy Department, Gweru, Zimbabwe \\ ${ }^{2}$ Midlands State University, Department of Land and Water Resources Management, Gweru, Zimbabwe \\ ${ }^{3}$ International Crop Research Institute for Semi-Arid Tropics (ICRISAT), Matopos Research Station, Bulawayo, \\ Zimbabwe \\ Email: ${ }^{\text {madanzit@msu.ac.zw }}$
}

Received 12 March 2014; revised 10 April 2014; accepted 21 April 2014

Copyright (C) 2014 by authors and Scientific Research Publishing Inc.

This work is licensed under the Creative Commons Attribution International License (CC BY). http://creativecommons.org/licenses/by/4.0/

c) (i) Open Access

\begin{abstract}
A study to assess the effect of intercropping maize (Zea mays L.) and cowpea (Vigna unguiculata L.) within the same basin or outside the basin on root length density (RLD) was conducted at the International Crop Research Institute for Semi-Arid Tropics (ICRISAT) Matopos Research Station from December 2009 to April 2010. The experiment was laid out in a Randomised Complete Block Design (RCBD) with four treatments replicated four times namely; sole maize, sole cowpea, maizecowpea intercrop with cowpea and maize planted within the same basin and maize-cowpea intercrop with cowpea planted $20 \mathrm{~cm}$ outside the maize basin. There was significant difference $(\mathrm{P}<$ 0.001) in RLD, grain yield and stover yield. Maize-cowpea intercropped within the same basin achieved higher RLD, grain yield and stover yield than cowpea that was intercropped outside the basin and the sole crops. The land equivalent ratio (LER) in both intercrop designs showed that intercropping had better grain yield performance when compared to sole cropping. It can be concluded that intercropping maize and cowpeas within the same basin can result in an environment around the crop achieving higher RLD which translates to better grain yield compared to the sole cropping and intercropping cowpeas outside the basin.
\end{abstract}

\section{Keywords}

Intercropping, Competition, Root Length Density, Grain Yield

\footnotetext{
${ }^{*}$ Corresponding author.
} 


\section{Introduction}

In Zimbabwe agro ecological region III - V constitute about 57\% of the total land with region III making up $17.4 \%$, region IV 33\%, and region V $26.2 \%$ of the total land [1]. These agro ecological regions carry about $46.34 \%$ of the total population in Zimbabwe and are characterized by periodic droughts and low erratic rainfall [2]. These conditions have ensured that food security is rarely achieved by the smallholder farmers who attain yields of less than one tonne per hectare and as a result these agro ecological zones have the highest incidence of poverty in Zimbabwe [3]. Farmers in these regions have been encouraged to grow drought tolerant crops such as sorghum (Sorghum bicolour L.) as well as practice intercropping in order to improve food security but however they still prefer maize which usually does not do well [4].

Conservation agriculture (CA) has also been promoted in these areas as a mitigation measure and has proved to be successful in improving crop yields [5]. CA is defined as a way of farming that makes more efficient use of natural resources through integrated management of available resources [3]. The tillage systems used in CA are widely accepted as ways of reducing some of the negative impacts of conventional tillage such as soil erosion, leaching and runoff of agricultural chemicals. In Zimbabwe the ripper tillage system and the basin tillage system are mainly used with the latter being favoured despite the fact that it is labour intensive. The basin tillage system is more popular amongst the resource poor farmers as it only requires a hand held hoe as a tillage implement whilst the ripper tillage system requires animal draught power that some farmers might not have [5]. Shortage of draught power has been found to result in farmers resorting to faster means of tillage with little control on planting depth resulting in poor crop establishment leading to lower yields in crop production [6]. Research has also shown that planting basins have a better water retention capacity as compared to the ripper tillage system and thus increases yields by $15 \%$ - $75 \%$ in semi-arid areas [7].

The recommended plant population for maize in arid and semi-arid areas such as those found in natural region III - V in Zimbabwe is between 20,000 and 33,000 plants $\cdot \mathrm{ha}^{-1}$ [8]. These low plant densities result in a substantial amount of land being left bare which can be countered by intercropping. One of the main principles of CA encourages farmers to mix and rotate crops of different species [9]. The mixing of crops of different species ensures maximum exploration of the different layers of the soil profile at different times which will result in less competition between the component crops and attainment of better yield [10]. [11] advocated that intercropping increased crop productivity and yield in dry areas. This is achieved through the modification of the canopy environment which reduces the amount of solar radiation reaching the ground thus resulting in lower soil temperatures and reduced soil evaporation. Intercropping also helps smother weeds that may compete with the crops for soil moisture [12]. Leguminous crops, such as cowpea, are favoured in intercrop systems as they help improve the soil nitrogen content as well as acting as live mulch which helps in moisture conservation [9].

Information on the development of the root system especially under intercrop system is very important as root development is an integral part of crop growth. The temporal and spatial distribution of root length densities and root mass are important for characterization and modelling of water and nutrient uptake and plant biomass as well as crop [13]. There are a number of factors that contribute to the distribution of crop roots in the soil such as the soil type, moisture content and bulk density. Previous studies [14] showed that as bulk density increased down the soil profile root length density (RLD) of maize decreased and that yield of maize was significantly low when the bulk density was higher than the threshold. These studies were also able to show that when the soil moisture environment was high, root penetration resistance was greatly reduced hence more soil exploration by the root system [15]. Root length density studies can thus be able to aid in determining whether intercropping is beneficial or not.

Although a number of studies have been carried out on the subject of root length density in sole crops such as maize, no research has been carried out on the effect of intercropping cowpeas with maize using the basin tillage system on root length density [16]. The aim of this study was to determine how root length density is affected by intercropping using the basin tillage system under semi-arid conditions.

\section{Materials and Methods}

\subsection{Study Site Description}

The study was conducted south of Zimbabwe at the International Crops Research Institute for the Semi-Arid Tropics (ICRISAT) Matopos research station in agro-ecological region IV during the 2009/2010 agricultural 
season. The station is located $28.5 \mathrm{~km}$ outside the city of Bulawayo at $\left(28^{\circ} 30.92^{\prime} \mathrm{E}\right)$ and $\left(20^{\circ} 23.32^{\prime} \mathrm{S}\right)$. The site is characterized by semi-arid climatic conditions receiving unimodal rainfall averaging $450 \mathrm{~mm}$ to $650 \mathrm{~mm}$ per annum [1]. The site has mainly clay soils classified as shallow Silliatic (4.E.1) according to the Zimbabwean soil classification system [17]. The rainfall is poorly distributed and mid-season droughts are common.

\subsection{Experimental Design}

Randomized complete block design with four treatments namely sole maize, sole cowpea, maize-cowpea intercrop with cowpea inside the basin and maize-cowpea intercrop with cowpea outside the basin at a distance of 20 $\mathrm{cm}$ replicated four times was used in this study. The blocking factor was slope of the land. The gross plot size was $90 \mathrm{~m}^{2}$ with dimensions $15 \mathrm{~m} \times 6 \mathrm{~m}$ per plot and the net plot size was $70 \mathrm{~m}^{2}$ with dimensions $14 \mathrm{~m} \times 5 \mathrm{~m}$. Planting basins of dimension $15 \mathrm{~cm} \times 15 \mathrm{~cm} \times 15 \mathrm{~cm}$ were used with an inter row spacing of $90 \mathrm{~cm}$ and an intra-row spacing of $60 \mathrm{~cm}$.

\subsection{Treatments}

Variety used for maize was seed co SC 403 which is best suited for natural region IV and V variety used for cowpeas was CBC1. The treatments were set out as follows; sole maize variety SC 403, sole cowpeas variety $\mathrm{CBC} 1$, maize and cowpeas intercrop with cowpeas planted outside the basin and maize cowpeas planted within the same basin.

\subsection{Management of Experimental Variables}

Planting basins were prepared in mid-October 2009 well before the first effective rains of the season. Compound D (7\%N: 14\%P: 7\%K) fertilizer was applied at a rate of $93 \mathrm{~kg} \cdot \mathrm{ha}^{-1}$ after basin establishment. Maize was planted during the first week of December 2009 on the 6th with 3 seeds being planted per station then the seedlings thinned to two plants to obtain the optimum plant population of 37,000 plant $\cdot \mathrm{ha}^{-1}$. Ammonium Nitrate (AN) $34.5 \%$ nitrogen fertilizer was applied at the 5 - 6 leaf stage at a rate of $83 \mathrm{~kg} \cdot \mathrm{ha}^{-1}$. Cowpea was planted 28 days after maize to enable establishment of the maize without the competitive effects of cowpeas if planted at the same time. Three pips of cowpeas were planted in the basin and thinned to two plants in sole stands. In the intercrop type with cowpeas planted within the same basin as maize 3 pips were planted in the basin. In intercrop with cowpeas outside the basin 2 pips were planted and then thinned to one.

All the trial plots were kept weed free by hand hoeing throughout the season. Due to the fact that basins were made about almost two months before the start of the experiment, the disturbance of the soil managed to control weeds in the first few days after planting with the first weeding taking place two and half weeks after planting and the second weeding done 6 weeks after planting before applying AN fertilizer. After the $6^{\text {th }}$ week the crop was able to smother weeds naturally.

\subsection{Measurements}

\subsubsection{Root Sampling}

Root length densities of maize, samples were taken halfway between planting stations at random from each treatment within the net plot area with three plants being sampled in each plot according to a method used by Materechera and Mloza-Banda, 1997 [18].

A $10 \mathrm{~cm}$ diameter $\times 10 \mathrm{~cm}$ height bucket auger was used to collect root core sample cores. Root samples were collected up to depth of $40 \mathrm{~cm}$ as this was the deepest allowable depth in the soil profile. Samples were collected at a distance of $5 \mathrm{~cm}$ away from each plant.

\subsubsection{Root Length Measurements}

After the root core samples were collected from the field they were air dried for four days and then ground in a Jefferson and Mott small mill to break the soil clods. Sub samples weighing $50 \mathrm{~g}$ were collected from each main sample and soaked overnight in sodium hexametaphosphate to separate the soil from the roots. The samples were then washed with water in a 53 micrometer sieve mash. Root length was determined using the line intercept method described below. 


\subsubsection{Line Intercept Method}

Safranin red was added to the trapped roots to improve contrast. The roots were then spread on a thin layer of water on a transparent acetate folio. A glass plate with one centimetre grid was placed on top. The horizontal and vertical interceptions of the roots with grid lines were then counted and added together. The following formula was used to calculate root length:

$$
L=\frac{\Pi N \mathrm{~A}}{2 H}[19]
$$

where $\mathrm{L}$ is the root length, $\mathrm{N}$ is the number of intersections between the roots and the straight lines, $\mathrm{A}$ is the area on the grid of each square and $\mathrm{H}$ is the total length of the straight line.

\subsubsection{Bulk Density}

Bulk density was measured at the same depth as the root core samples using a bucket auger $10 \mathrm{~cm}$ diameter $\mathrm{x} 10$ $\mathrm{cm}$ height to collect the soil cores. Cores were collected at depths $0-10,10-20$ and $30-40 \mathrm{~cm}$. The samples were placed in labelled paper bags and weighed straight away. The samples were then oven dried at $105^{\circ} \mathrm{C}$ for at least 24 hours until a constant weight was reached and then re weighed. The following formula was used to calculate bulk density:

$$
\text { Bulk density }\left({ }^{b} \rho d\right)=\frac{\text { mass of even dry soil }(\mathrm{g})}{\text { Volume of sampling core }\left(\mathrm{cm}^{3}\right)} \quad \text { [20] }
$$

\subsubsection{Root Length Density (RLD)}

Root length density was then calculated as follows:

$$
\text { RLD }=\text { Root Length } \times \text { Average Bulk Density at each depth }
$$

\subsubsection{Grain Harvesting and Yield Measurement}

Harvesting in the maize plots was done at physiological maturity. Ten seeds were collected at random from each plot weighed and dried in an oven and re-weighed to determine grain moisture content. The grain weight was then corrected for moisture content.

$$
\text { Grain Yield }(\mathrm{Y})=\mathrm{FWP} \times \mathrm{DM} \times \mathrm{M} \times \mathrm{F}
$$

where $\mathrm{Y}=$ Grain yield in $\mathrm{Kg} \cdot \mathrm{ha}^{-1}$ at $12.5 \%$ moisture

FWP $=$ Fresh weight of the net plot in kg

$\mathrm{DM}=$ Fraction of dry matter in sample (dry weight/fresh weight) in $\mathrm{kg}$

$\mathrm{M}=$ Moisture factor (100/87.5) for $12.5 \%$ moisture

$\mathrm{F}=$ Conversion factor from $\mathrm{g} \cdot$ net $^{-1} \mathrm{plot} \mathrm{kg} \cdot \mathrm{ha}^{-1}$

\subsubsection{Land Equivalent Ratio}

To measure the efficiency of intercropping maize and cowpea, the land equivalent ratio method was used as follows: LER = Intercrop A yield/sole crop yield A + intercrop B yield/sole crop2 yield [21].

\subsubsection{Gross Margin Analysis}

Gross Margin Analysis $=$ Total income - Total variable costs [22] .

\subsection{Data Analysis}

Analysis of variance ANOVA was performed on all data collected using Genstat 3 Discovery edition. Least significant difference LSD was used to separate the treatment means at $5 \%$ level of significance.

\section{Results}

\subsection{Maize Root Length Density}

There was significant difference $(\mathrm{P}<0.001)$ in maize root length density. The intercrop with maize and cowpeas 
planted within the same basin achieved the highest RLD with mean RLD of $74.64 \mathrm{~cm} \cdot \mathrm{cm}^{-3}$ (Figure 1). Sole maize had the second highest RLD OF $59.60 \mathrm{~cm} \cdot \mathrm{cm}^{-3}$ while the intercrop with maize planted outside the basin had the lowest RLD of $46.82 \mathrm{~cm} / \mathrm{cm}^{3}$. There was a decrease in root length density as the soil depth increased.

\subsection{Cowpeas Root Length Density}

Cowpeas root length density was significantly different $(\mathrm{P}<0.05)$ between the treatments with the intercrop with cowpeas planted within the same basin as maize achieving the highest mean RLD of $56.95 \mathrm{~cm} \cdot \mathrm{cm}^{-3}$, followed by intercrop type with cowpeas outside the basin (Figure 2). There was also a decrease in root length density as soil depth increased.

\subsection{Grain and Stover Yield}

Maize grain was significantly different $(\mathrm{P}<0.001)$ between the treatments with maize and cowpeas intercrop planted within the same basin achieving the highest grain yield of $1789 \mathrm{~kg} \cdot \mathrm{ha}^{-1}$ followed by sole maize with $1226 \mathrm{~kg} \cdot \mathrm{ha}^{-1}$ and intercrop with cowpeas outside the basin obtaining yield of $1204 \mathrm{~kg} \cdot \mathrm{ha}^{-1}$ (Table 1). There was also significant difference $(\mathrm{P}<0.001)$ in maize stover yield with the intercrop that was planted within the basin achieving higher stover yield compared to the intercrop planted outside the basin and the intercrop which achieved the same yield statistically.

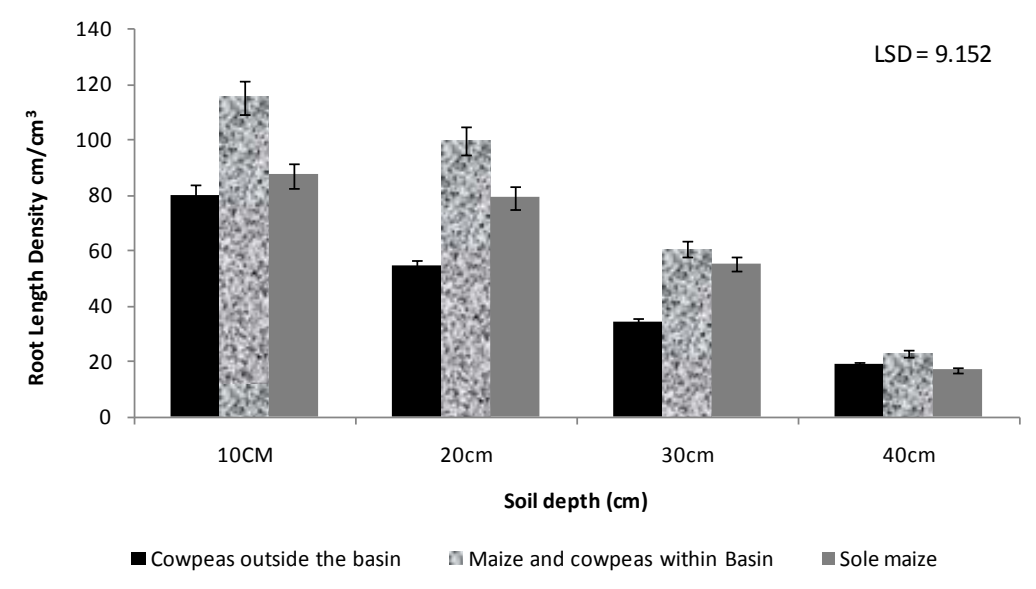

Figure 1. Maize root length density.

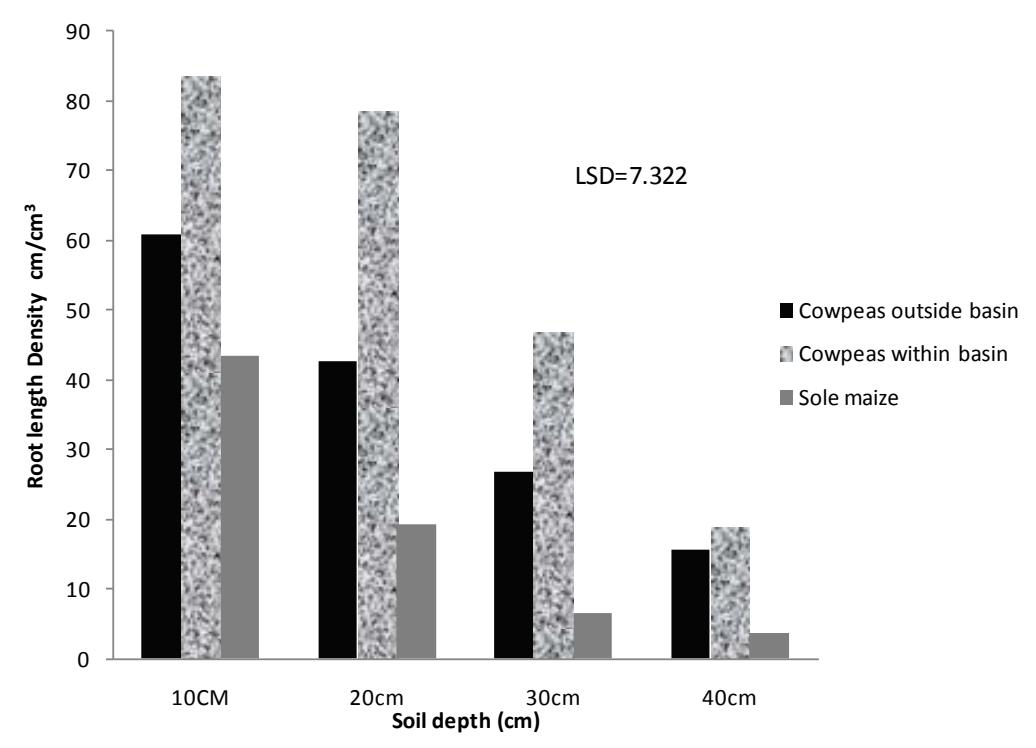

Figure 2. Cowpeas root length density. 
There was significant difference $(\mathrm{P}<0.001)$ in both grain and stover yield of cowpeas planted as a sole crop and when planted as an intercrop (Table 2). For both grain and stover, cowpea intercropped with maize within and outside the basin achieved higher yield than cowpea planted as a sole crop. However, although cowpea planted within the same basin with maize achieved slightly higher yield, it was not statistically different to the one intercropped outside the basin.

\subsection{Land Equivalent Ratio}

Land equivalent ratio of all the intercrop types were found to be greater than 1.0 (Table 3). Intercrop with maize and cowpeas within same basin achieved the greatest LER of 2.86 as compared to the intercrop where cowpeas were planted outside the basin, which had an LER value of 2.02 .

\subsection{Gross Margin Analysis}

Both intercrop types had high returns as compared to sole crops with intercrop type B having the highest return of US\$506.37, followed by intercrop type A with US\$351.16 (Table 4). All the sole crops had the least returns maize had US\$276.95 and cowpeas had a low gross margin of US\$4.04.

\section{Discussion}

\subsection{Root Length Density}

Maize grown under intercrop with cowpeas within the same planting basin recorded the highest root length density

Table 1. Maize grain and stover yield.

\begin{tabular}{|c|c|c|}
\hline Treatment & Maize yield $\mathrm{kg} \cdot \mathrm{ha}^{-1}$ & Maize stover $\mathrm{kg} \cdot \mathrm{ha}^{-1}$ \\
\hline Sole Maize & $1226^{\mathrm{b}}$ & $1614^{\mathrm{b}}$ \\
\hline Sole Cowpeas & - & - \\
\hline Intercrop same basin & $1789^{\mathrm{a}}$ & $2203^{\mathrm{a}}$ \\
\hline Intercrop outside basin & $1335^{\mathrm{b}}$ & $1521^{\mathrm{b}}$ \\
\hline Grand mean & 1450 & 1779 \\
\hline Significance level & $<0.001$ & $<0.001$ \\
\hline L.S.D (0.05) & 173.0 & 130.4 \\
\hline C.V\% & 6.9 & 4.2 \\
\hline
\end{tabular}

Table 2. Cowpea grain and stover yield.

\begin{tabular}{ccc}
\hline Treatment & Cowpeas kg $\cdot \mathrm{ha}^{-1}$ & ${\text { Cowpea stover kg } \cdot \mathrm{ha}^{-1}}^{\mathrm{a}}$ \\
Sole Maize & - & $447^{\mathrm{b}}$ \\
Sole Cowpeas & $439^{\mathrm{b}}$ & $849^{\mathrm{a}}$ \\
Intercrop same basin & $717^{\mathrm{a}}$ & $820^{\mathrm{a}}$ \\
Intercrop outside basin & $708^{\mathrm{a}}$ & 705 \\
Grand mean & 621 & $<0.001$ \\
Significance level & $<0.001$ & 112.1 \\
L.S.D (0.05) & 113.2 & 9.5 \\
C.V\% & 10.5 & 9.5 \\
\hline
\end{tabular}


Table 3. Land equivalent ratios.

\begin{tabular}{ccccc}
\hline Treatment & Maize & Cowpeas & LER & Percentage difference \\
\hline Sole Maize & 1.00 & - & 1.00 & - \\
Sole cowpeas & - & 1.00 & 1.00 & + \\
Outside basin & 1.09 & 0.93 & 2.02 & +102 \\
Within basin & 1.46 & 1.40 & 2.86 & +186 \\
\hline
\end{tabular}

Table 4. Gross margin analysis (In US\$).

\begin{tabular}{cccccc}
\hline Treatment & $\begin{array}{c}\text { Total variables } \\
\text { (US\$) }\end{array}$ & $\begin{array}{c}\text { Maize Income } \\
\text { (US\$) }\end{array}$ & $\begin{array}{c}\text { Cowpeas Income } \\
\text { (US\$) }\end{array}$ & $\begin{array}{c}\text { Total Income } \\
\text { (US\$) }\end{array}$ & $\begin{array}{c}\text { Gross Margin } \\
\text { (US\$) }\end{array}$ \\
\hline Cowpeas outside basin & 75.80 & 367.12 & 59.84 & 426.96 & 351.16 \\
Within basin & 75.80 & 491.97 & 90.20 & 582.17 & 506.37 \\
Sole maize & 60.20 & 337.15 & - & 337.15 & 276.95 \\
Sole cowpeas & 60.20 & - & 64.24 & 64.24 & 4.04 \\
\hline
\end{tabular}

as compared to the sole crop and the intercrop with cowpeas planted outside the basin. This could have been due to the basin reducing water loss due to runoff thereby maintaining higher moisture content around the root zone of the crop. This moisture resulted in reduced soil penetration resistance for the roots of the component crops resulting in a higher RLD compared to the sole crop. Intercropping also gave a live mulch on the soil surface and thereby reducing both soil temperature and evapotranspiration. This is in agreement with [23] who noted that plant root depth and distribution in the soil is controlled by factors such as the rooting environment (soil moisture content and temperature). This is however in contradiction with findings by other researcher who found that extraction of moisture is very high when the number of plants per planting station is high resulting in faster depletion of moisture from the soil there by increasing root penetration resistance resulting in poor RLD [24]. The difference perhaps was due to the basin tillage method being used in this study which has better water retention capacity.

\subsection{Effect of Intercropping on Grain Yield}

In this study both the grain yield of maize and cowpea planted within the basin and outside the basin was higher than sole crop maize and cowpea. The high maize grain yield perhaps could have been due to the fact that basin reduced runoff and allowed water to be harvested closer to the crop. The higher yield could also have been due to reduced competition for soil moisture and nutrients between the component crops due to the difference in maturing and grain filling times of the maize and cowpeas. Cowpea also matures earlier before the maize flowering stage thus reducing completion for resources. This is in agreement with [25] who noted that in an intercropped system cowpeas matured when the maize was flowering thus reducing the competition between the maize and the cowpeas during the grain filling stage of the maize crop. Another factor that could have contributed to the high maize grain yield is that of reduced evapotranspiration of the component crops resulting in better water use efficiency. This agrees with [10] who found out that the modification of the light environment by the plant canopy affected positively the water relations of the intercropped plants by increasing the water use efficiency which would result in increased yields particularly benefiting farmers who live in the arid and semi-arid areas like those found in natural region III-IV in Zimbabwe. Modification of the light environment also means that the soil temperatures are kept to at a minimum hence less moisture is lost to the atmosphere through soil surface evaporation hence maintaining the soil moisture regime thus increasing water use efficiency by the component crops.

\subsection{Effect of Intercropping on Stover Yield}

The Intercrop with maize and cowpeas planted within the same basin and that intercropped outside the basin 
recorded the highest stover yield which was statistically the same for both maize and cowpeas compared to the sole crops. This could have been due to the fact that basins resulted in more water being harvested while the higher vegetative biomass in the intercrops resulted in improved water use efficiency as compared to the sole crops. The higher stover yield could also have been due to less root penetration resistance due to higher soil moisture around the root zone in the intercrops. This is in agreement with [16] who found that intercropping increased the biomass of the component crops due to the increased nutrient if one of the intercrops was a legume and better moisture regime within the stands as compared to sole stands.

\subsection{Efficiency of Intercropping}

The land equivalent ratios were all above 1.0. This showed that intercropping was advantageous over sole cropping with intercrop of maize and cowpeas planted within the same basin obtaining the highest LER of 2.86. This meant that the intercropped area would produce more than twice as much yield as sole cropped stands of the same area. This again could perhaps be attributed to the fact of better utilisation of water and radiation by the intercropped stands. These results are in agreement with a study on productivity of maize and cowpeas under intercrop systems [25] which attributed better performance of intercrops to improved water and radiation use compared to sole crops. The gross margin analysis also indicated that intercropping had better financial returns than sole cropping with the crop that was intercropped within the same basin achieving a higher return than the crop which was intercropped outside the basin or the sole crops.

\section{Conclusions}

Intercropping maize and cowpeas within the same basin resulted in high root length densities which translated to higher yields for both the maize and cowpeas as compared to sole crops or intercropping outside the basin. Intercropping also had significant effects on the maize and cowpea stover, with intercropping resulting in higher stover yield compared to the sole crops. The LER also showed that intercropping had a major advantage over sole cropping particularly when the maize and cowpea are planted within the same basin. The gross margin analysis also outlined the fact that intercropping was beneficial as compared to sole stands as both intercrops had higher returns particularly Intercrop with maize and cowpeas planted within the same basin.

Conservation farming coupled by intercropping conserves the soil as well as improves soil fertility which translates to better yields. Intercropping maize and cowpea within the same basin particularly under conservation farming using the basin tillage system proved to produce better yields and would be highly recommended to the communal farmer. Intercropping not only generates a better income but also improves the nutritional diversity of the household and would be recommended to the small holder communal farmer. However, further investigations are required as soil physical properties and environment are a transitory process and therefore one year may not have been adequate. Further studies that can be carried out are over different soils and the impact of basins on weed growth and development as well as on soil moisture content.

\section{Acknowledgements}

We would like to thank the International Crops Research Institute for the Semi-Arid Tropics (ICRISAT) Matopos for allowing us to carry out this study. We would also like to thank Bheki and Getrude the field assistants at ICRISAT for their cooperation during data collection.

\section{References}

[1] Vincent, V. and Thomas, R.G. (1961) Part I: Agro-Ecological Survey of Southern Rhodesia. Government Printers, Salisbury, 124.

[2] Rukuni, M. and Eicher, C. (1994) Zimbabwe Agricultural Revolution. University of Zimbabwe Publications, Harare.

[3] FAO (2003) Conservation Agriculture in Zimbabwe. FAO, Rome, 2.

[4] Nyamudeza, P. (1998) Rainfed Cropping and Water Conservation on Vertisols in the South Eastern Lowveld of Zimbabwe. Proceedings of a Workshop on Vertisols Management in Africa, Harare.

[5] Hove, L. and Twomlow, S. (2008) Is Conservation Agriculture an Option for Vulnerable Households in Southern Africa? The Conservation Agriculture for Sustainable Land Management to Improve the Livelihood of People in Dry 
Land Areas Workshop, Damascus, 7-9 May 2007.

[6] Madanzi, T., Chiduza, C. and Richardson-Kageler, S. (2010) Effects of Planting Method and Seed Size on Stand Establishment of Soybean [Glycine max (L.) Merrill c.v. Solitaire]. Soil and Tillage Research, 106, 171-176. http://dx.doi.org/10.1016/j.still.2009.12.003

[7] Goddard, T., Zoebisch, M.A., Gan, Y.T. and Sombatpaint, S. (2008) No Till Farming Systems. Special Publication Number 3, World Association of Soil and Water Conservation, Bangkok, 169p.

[8] Agronomy Institute (1993) Summer Report. Department of Research and Specialist Services, Ministry of Lands and Agriculture, Harare.

[9] Twomlow, S., Urolov, J.C., Jenrich, M. and Oldrieve, B. (2008) Lessons from the Field—Zimbabwe's Conservation Agriculture Task Force. Journal of SAT Agricultural Research, 6, 1-11. http://www.icrisat.org/journal/Volume6/aes/Twomlow.pdf

[10] Lima Filho, J. (2000) Physiological Responses of Maize and Cowpeas to Intercropping. Agropec. Brasillia, 35, 915921. http://www.scielo.br/pdf/pab/v35n5/4712.pdf

[11] Nzabi, A.W., Makini, F., Onyongo, M., Kidula, N., Muyonga, C.K., Miruku, M., Mutai, E. and Gesare, M. (2000) Effects of Intercropping Legume with Maize on Soil Fertility and Maize Yield. Proceedings of the 2nd Scientific Conference of the Soil Management and Legume Research Network Projects, Mombasa, June 2000.

[12] Chatterjee, B.N., Mati, S. and Mandal, B.N. (1989) Cropping Systems-Theory and Practice. 2nd Edition, Oxford and IBH Publishing, New Delhi, 121-185.

[13] Van Noordwijk, M. and Van DeGeijn, S. (1996) Rootshoot and Soil Parameters Required for Process Oriented Models of Crop Growth Limited by Water or Nutrients. Plant and Soil, 183, 1-25. http://dx.doi.org/10.1007/BF02185562

[14] Kuchenbuch, R.O. and Ingram, B. (2004) Effects of Soil Bulk Density on Seminal and Lateral Root of Maize Plants. Journal of Plant Nutrition and Soil Science, 167, 229-235. http://dx.doi.org/10.1002/jpln.200320352

[15] Goodman, A.M. and Ennos, A.R. (1999) The Effects of Soil Bulk Density on the Morphology and Anchorage Mechanics of the Root Systems of Sunflower and Maize. Annals of Botany, 83, 293-302. http://dx.doi.org/10.1006/anbo.1998.0822

[16] Eskandari, H. and Ghanbari, A. (2009) Intercropping of Maize and Cowpea as Whole-Crop Forage: Effect of Different Planting Pattern on Total Dry Matter Production and Maize Forage Quality. Notulae Botanicae Horti Agrobotanicae Cluj Napoca, 37, 152-155.

[17] Nyamapfene, K.W. (1991) The Soils of Zimbabwe. 2nd Edition, Nehanda Publishers, Harare, 179p.

[18] Materechera, S.A. and Mloza-Banda, H.R. (1997) Soil Penetration Resistance, Root Growth and Yield of Maize as Influenced by Tillage System on Ridges in Malawi. Soil and Tillage Research, 41, 13-24. http://dx.doi.org/10.1016/S0167-1987(96)01086-0

[19] Newman, E.I. (1966) Methods of Estimating the Total Length of Roots in a Sample. Journal of Applied Ecology, 3 , 139-145. http://www.jstor.org/stable/2401670 http://dx.doi.org/10.2307/2401670

[20] Buckman, H.O. and Brady, N.C. (1999) The Nature and Properties of Soils. 12th Edition, Upper Prentice Hall.

[21] Mead, R. and Willey, R.W. (1980) The Concept of a "Land Equivalent Ratio” and Advantages in Yields from Intercropping. Experimental Agriculture, 16, 217-228. http://dx.doi.org/10.1017/S0014479700010978

[22] Sullivan, P. (1998) Intercropping Principles and Production Practices. Appropriate Technology Transfer for Rural Areas (ATTRA). Fayettiville Publications, Arizona, 230p. http://www.iatp.org/files/Intercropping_Principles_and_Production_Practi.htm

[23] Jones, C.A., Bland, W.L., Ritchie, J.T. and Williams, J.R. (1991) Simulation of Root Growth. In: Hanks, J. and Ritchie, J.T., Eds., Modeling Plant and Soil Systems, American Society of Agronomy, Madison, 91-123.

[24] Konopka, B., Pages, L. and Doussan, C. (2009) Soil Compaction Modifies Morphological Characteristics of Seminal Maize Roots. Plant Soil Environ, 55, 1-10. http://www.agriculturejournals.cz/publicFiles/03485.pdf

[25] Nyakatawa, E.Z. and Kamba, E. (1996) Productivity of Maize and Cowpeas Sole Crops and Intercrop System on Black Vertisols of the South-East Lowveld of Zimbabwe. In: Ransom, J.K., Palmer, A.F.E., Zambezi, B.T., Mduruma, Z.O., Waddington, S.R., Pixley, K.V. and Jewell, D.C., Eds., Maize Productivity Gains through Research and Technology Dissemination. Proceedings of the Eastern and Southern Africa regional Maize Conference, Arusha, 3-7 June 1996, CIMMYT, Addis Ababa, 123-125. 